\title{
The relationship between financial reporting standards and accounting irregularities: Evidence from US banks
}

\author{
Ali Ihsan Akgün \\ Department of Health Management, Ankara Yildirim Beyazit University, Ankara, \\ Turkey \\ Yener Altunbas \\ Business School, Bangor University, Bangor, UK, and \\ Yurtsev Uymaz \\ Norwich Business School, University of East Anglia, Norwich, UK
}

\begin{abstract}
Purpose - The purpose of this paper is to explore whether the choice of International Financial Reporting Standards (IFRS) vs Generally Accepted Accounting Principles (GAAP) is associated with the frequency and likelihood of accounting irregularities and fraud in US banks.

Design/methodology/approach - The authors examine the relationship between financial reporting standards and accounting irregularities in publicly listed US banks. Using a sample of 4,284 banks with accounting irregularities observed in the USA over the period of 19962014. They used logit model to estimate the likelihood of corporate misreporting having been committed in terms of accounting irregularities.
\end{abstract}

Findings - The authors show that banks that use US GAAP exhibit better operating performance than fraudulent banks that use IFRS except for certain variables. They also find that fraudulent banks are more likely to commit accounting irregularities when they have to follow IFRS and banks have relatively better bank performance.

Practical implications - Overall, the empirical findings result consistent with Kohlbeck and Warfield's (2010) find that accounting standards are linked to fewer accounting irregularities.

Originality/value - In this study, accounting irregularities have a significant effect on bank performance during the Dodd-Frank period. It finds that banks that choose to use IFRS are more likely to have accounting irregularities and to engage in fraud.

Keywords International Financial Reporting Standards, Bank Performance, Accounting Irregularities, The Dodd-Frank Act

Paper type Research paper 


\section{Introduction}

Accounting practices (e.g. differences in financial reporting) can differ not only between countries but also within countries. To reduce these differences, both the International Accounting Standards Board and the European Union (EU) have issued regulations 1606/ 2002 and directives on financial reporting (Nobes and Parker, 2008) in the past decade. Transitioning to the mandatory International Financial Reporting Standards (IFRS) became an obligation in listed companies and regulated industries (e.g. banking and insurance companies) in the EU in 2005.

In the USA, however, financial reporting is prepared according to Generally Accepted Accounting Principles (GAAP). Thus, as US companies are not yet mandated to apply IFRS, non-US firms can apply to financial reporting under US standards (Petersen and Plenborg, 2012). Accounting irregularities are a serious event in the US economy, and the Securities and Exchange Commission (SEC) has publicized accounting irregularities over the previous years, with many more businesses changing their financial reporting practices to prevent repetition. Over this period, the SEC stated that $55 \%$ of firms had unsuitable revenue recognition approaches. Similarly, the USA General Accounting Office (GAO) found in its survey that $38 \%$ of all accounting irregularities involve revenue recognition timing errors and that over $10 \%$ of all listed firms in the US announced at least one accounting irregularity between 1997 and 2002. However, a movement toward addressing accounting irregularities in the US economy concluded in the Sarbanes-Oxley Act in 2002 (Coffee, 2005). Subsequently, in 2007, the SEC permitted non-US firms that use IFRS to file financial statements without settlement to US GAAP. Therefore, IFRS-based financial reporting information has become comparable to US GAAP-based information (Barth et al., 2012).

Globally, the USA is unquestionably the largest and most important economy and the total value of its stock markets exceeds those of all other countries. More importantly, financial 
reporting outcomes under US GAAP are commonly considered to be of high quality. Moreover, the public enforcement system in the USA is complemented by strong private enforcement that threatens lawsuits as well as substantial monetary penalties for executives and corporations that engage in accounting irregularities (Hail et al., 2010).

Nonetheless, because of the development of information and communication technologies, accounting irregularities in business have increased dramatically (Bolton and Hand, 2002). The dramatic collapses of huge corporations such as WorldCom, Enron and Global Crossing, were due to incidences of accounting irregularities (Law, 2011). Accounting irregularities can have three main outcomes. First, these cases have damaged confidence in financial markets (Law, 2011). Second, accounting irregularities can diminish shareholders' value maximization and business performance (Palmrose et al., 2004) or mislead shareholders about financial conditions. Finally, they can weaken the regulation of banking systems if banks are particularly large (Altunbas_ et al., 2018). Consequently, accounting irregularities can lead not only to significant risks for shareholders and other financial information users but also to financial crises.

In many countries, IFRS are considered to provide an ineffective legal enforcement of accounting and financial reporting regulations. Indeed, investors expect lower rates of errors and fraud when firms use US GAAP than IFRS. El-Gazzar and Finn (2017), for example, find different market reactions to the restatement surprise by US GAAP firms compared with IFRS firms. Their findings suggest that the use of IFRS by US firms does not result in significantly different financial reporting quality than US GAAP. Dechow et al. (1996) find no evidence that executives in GAAP firms manipulate earnings for personal gain. On the contrary, Nisbett and Sheikh (2007) suggest that financial misconduct is more likely to occur in the rule-based USA than in other countries. 
Another strand of the literature focuses on manipulated financial reporting, which can reduce a firm's equity (Murphy et al., 2009), have a devastating effect on a company's shareholders and employees, and ruin a firm's reputation and credibility (Pai et al., 2011; Zahra et al., 2007), and thus its cash flow. Bolton and Hand (2002) show that both managers and shareholders can benefit from misreporting. Some studies find that holdings can provide incentives for managers to misstate accounting numbers (Harris and Bromiley, 2007; Efendi et al., 2007), whereas others find no such significant association (Armstrong et al., 2010; Baber et al., 2009). Few studies (O’Connor et al., 2006; Burns and Kedia, 2008), however, show that equity incentives can instead lessen management's desire to manipulate accounting numbers. Consequently, since manipulated financial statements can damage a firm's legality at a certain level, accounting irregularities represent a particularly serious threat to legality.

The third strand of research focuses on the link between corporate governance and financial reporting irregularities (Smaili and Labelle, 2015; Armstrong et al., 2010). Smaili and Labelle (2015), for example, find weak evidence that the governance mechanisms of firms reveal irregularities in financial reporting applications compared with a sample of control firms. Harris and Bromiley (2007) find a positive relationship between the incidences of accounting restatements and the ratio of stock options to total compensation, whereas Baber et al. (2009) and Jayaraman and Milbourn (2015) do not find any statistical association. Similarly, Armstrong et al. (2010) find no evidence of a positive association between CEOs' equity incentives and accounting irregularities.

In this study, we add to this strand of the literature by empirically examining the impact of accounting irregularities under the same or different systems of accounting standards on financial reporting by banks. In this context, it makes five contributions to the literature on accounting irregularities in banking. First, this study uses accounting irregularities as a criterion for measuring bank performance (cost efficiency, assets quality, profitability, loans ratio and 
capital ratios) in samples of fraudulent banks and non-fraudulent banks. Second, we examine the relationship between financial misconduct and banks' financial statements under US GAAP and IFRS to offer sound inferences on accounting irregularities under these two financial reporting regimes. Third, we explain this relationship by examining the role of accounting standards in accounting irregularities as described by the Securities Class Action Clearinghouse (SCAC), the Securities Exchange Commission (SEC)'s set of Accounting and Auditing Enforcement Releases (AAERs), and General Accounting Office (GAO) in enforcement releases. Fourth, we examine the effect on bank performance of monetary penalties during the pre-and post-IFRS adoption periods. Finally, we examine the effect of the Dodd-Frank Act on bank performance in the post-IFRS adoption period and after the 2008 global financial crisis.

The remainder of this paper is structured as follows. Section 2 explains the related literature and hypothesis development. Section 3 covers the data sample and methodology. Section 4 describes the empirical results and analysis. Finally, we conclude in Section 5.

2. Related literature and hypotheses development

\subsection{Review of the related literature}

Financial statements are a critical source of information for users such as investors, creditors, and other shareholders and therefore a common source of alleged accounting irregularities relied on by litigations. Accounting irregularities can be suspected in a criminal case and a conviction secured even when US GAAP has been adhered to Amiram et al. (2018). First, corporate governance mechanisms influence accounting practices and the quality of the financial reporting (Anderson et al., 2004). Similarly, the board of directors and its audit committee play a critical role in corporate governance practice. Consistent with this argument, the literature on accounting irregularities, namely, restatement, misrepresented financial statement and financial reporting quality shows that the composition and characteristics of the 
board influence its effectiveness (Smaili and Labelle, 2015; Uzun et al., 2004). More importantly, corporate governance practices improve listed firms' transparency and accountability to their shareholders under the IFRS (Rankin et al., 2012). This study focuses on accounting irregularities, with the main area of interest being the effects of IFRS and US GAAP on financial reporting by US banks.

Consistent with this idea, some prior studies argue that Armstrong et al.'s (2010) finding suggest no evidence of a positive relationship between CEOs' equity incentives and accounting irregularities, but that accounting irregularities occur less commonly in firms when CEOs have higher levels of equity incentives. Therefore, while stock-based compensation is a frequently cited and highly researched motivation for financial reporting misconduct, the evidence supporting it is mixed. Hence, several factors within firms have been identified to encourage accounting irregularities such as weak corporate governance structure. For example, Peng and Röell (2008) find that employee stock options raise the probability of private securities classaction litigation. Zhao and Chen (2008) and Fich and Shivdasani (2007) find that good governance practices significantly decrease financial reporting misconduct, suggesting that staggered boards mitigate the likelihoods of committing fraud under US GAAP. Their finding also suggests a negative relationship between staggered boards and business performance. Larcker et al. (2007) find no evidence of a relationship between corporate governance and accounting restatements and show that corporate governance indices provide little information relative to accounting restatements. Efendi et al. (2007) find that CEOs with extensive in-themoney options are likely to have a greater incentive to issue non-GAAP accounting irregularities.

Because accounting irregularities may involve the manipulation of financial statements by a variety of economic agents in financial markets under a legal regime, we consider that advances would benefit this strand of the literature. Our review thus examines opportunistic financial 
reporting behavior where accounting irregularities lie at the far right and acceptable earnings management strategies that convey private information that comply with the provisions of US GAAP (Amiramet al., 2018).

Prior studies examine the relationship between corporate governance mechanisms and either earnings management or the SEC's enforcement actions for violating GAAP (Dechow et al. (1996); Agrawal and Chadha, 2005). Several studies have examined earnings management by non-financial firms under IFRS (Wang and Campbell, 2012; Pelucio-Grecco et al., 2014; Ugrin et al., 2017). However, there is limited evidence on accounting irregularities in USA after IFRS adoption in the financial industry. Because of this gap, this study examines whether the changes in the financial reporting practices resulting from IFRS have decreased accounting irregularities in US listed financial firms and raised the quality of financial reporting information.

Empirical evidence has shown that earnings management has risen in European firms in the post-IFRS adoption period; however, the relationship between IFRS adoption and earnings management differs across countries. For example, Ugrin et al. (2017) show a significant effect of earnings management after the adoption of IFRS. Wang and Campbell's (2012) empirical findings suggest that IFRS application does not seem to prevent earnings management. PelucioGrecco et al. (2014) find that the convergence to IFRS has had a preventive effect on earnings management since the adoption of IFRS in Brazil. Perols and Lougee (2011) find that fraudulent firms are more likely to have managed earnings in previous years. Kohlbeck and Warfield (2010) show that earnings management has fallen since IFRS has been implemented. Desai et al. (2006) show that managers of firms committing GAAP violations do not appear to get away with earnings management. Whereas financial statement fraud has the same objective as earnings management under GAAP, it differs from earnings management in that fraud is outside local GAAP (Erickson et al., 2006). Hence, changes to accounting standards are likely 
to affect financial information systems and processes, as well as the regulatory capital of many banks. In our study, we suggest that accounting irregularities by definition occur when managers commit financial reporting fraud. Many empirical studies have been devoted to this issue under US GAAP, but scant evidence is available under IFRS. Our analysis bridges this gap in the literature by considering the impact of financial misconduct by US listed banks under US GAAP and IFRS.

Some studies provide mixed evidence on whether equity incentives cause executives to manipulate accounting information. Harris and Bromiley (2007), for example, find that both incentives and competitor performance influence financial statement misrepresentation. Erickson et al. (2006), Armstrong et al. (2009), and Core (2010) find no relationship between incentives and accounting irregularities. O'Connor et al. (2006) find that CEO stock option compensation is associated with a lower incidence of fraudulent reporting. By contrast, Johnson et al. (2009) find that the likelihood of corporate fraud is positively related to incentives from unrestricted stockholdings. Warren et al. (2011) show that the CEO's stock option compensation motivates the CEO to commit corporate earnings fraud. Efendi et al. (2007) state that the value of the CEO's option holdings affects not only the likelihood of a misstatement, but also the likelihood of severe accounting irregularities. In this research, we argue that accounting irregularities influence financial reporting standards.

IFRS allow cross-border information transfer and offer financial statement comparability. They also increase financial reporting comparability for disclosing information (Wang, 2014). Consequently, high quality financial reporting provides comparable and transparent financial information. Indeed, prior research shows that IFRS encourage transparency, comparability, harmonization and flexibility in financial reported practices by companies.

More importantly, although accounting irregularities is an emerging topic of great importance, a comprehensive literature review of the subject has yet to be carried out in terms of accounting 
standards. In this context, this study focuses on whether accounting irregularities are influenced by US GAAP and IFRS. In accordance with the regulation issued by the official journal of the European Community, IFRS must be applied to publicly traded companies in member states to contribute to the efficient and cost-effective functioning of community capital markets and thereby the completion of internal markets.

\subsection{Hypotheses development}

Reliable financial reporting is critical to the efficiency of financial markets. Several prior studies suggest that if financial statements are prepared according to sound accounting principles, investors can make informed investment decisions. However, although accurate financial reporting is important for investors, managers may have an incentive to misrepresent financial results for individual gain (Larcker and Taylan, 2010). Black (2005) suggests that fraud can produce real profits for schemers. Thus, misleading financial reporting can result in over-priced securities for a firm which can result in losses for firms and stockholders (Hefendehl, 2004).

This study provides evidence on the monetary penalties imposed on firms and their managers when overstatements that violate accounting practices are issued. It also examines the link between corporate governance and financial reporting irregularities (Judge et al., 2010; Hail et al., 2010). IFRS have important implications for national corporate governance practices, multinational firms, and trade flows within the global economy (Judge et al., 2010). An important role of accounting standards is to impose regulatory and compliance costs, which can increase the barriers to entry into financial markets (Hail et al., 2010). Overall, good corporate governance requires reliable financial reporting and information.

According to Kothari et al. (2010), IFRS are a principles-based method of financial reporting that suggests guidelines for preparing financial statements, whereas GAAP is a rules-based 
method that offers an inflexible set of detailed financial reporting standards. Empirical evidence has suggested that IFRS provide comparability for financial statements. However, some argue that the adoption of IFRS can trigger a loss of the quality that GAAP provides and result in increased accounting irregularities because of their flexibility (Ugrin et al., 2017).

The extensive literature on the relationship between financial reporting standards and accounting irregularities shows somewhat mixed findings. Studies show that firms that present accounting irregularities underachieve and have a worse financial situation than non-fraudulent firms. Not surprisingly, accounting irregularities have significantly negative effects. For example, Richardson et al. (2002) find that firms with restatements try to attract external financing at a lower cost. Spathis (2002) shows that significantly affects firms with false financial statements. Johnson et al. (2007) find a significant relationship between lawsuit filing and accounting irregularities.

According to Frost et al. (2009), evidence of the potential benefits of IFRS adoption from other countries is not essentially valid in the US context. One argues that US firms' accounting amounts usually have higher value relevance than those of IFRS firms consistent with the earlier research by Barth et al. (2012). Donelson et al.'s (2012) results show that rules-based US GAAP standards are linked to a lower rate of litigation but not to litigation outcomes.

IFRS, as noted earlier, provide international accounting harmonization, a high degree of transparency, and comparability of financial statements and thus can result in higher information quality than local GAAP. IFRS can also affect many areas of financial reporting, including the introduction of extensive disclosure requirements and financial statement presentation in the banks. In terms of the impact of financial consolidation on bank performance, banks are significantly affected by these accounting standards. More importantly, the accounting quality of a bank's financial statements is relevant not only to investors but also 
to bank supervisors because of their regulatory institutions. Therefore, we test the following hypothesis:

H1. There is a significant difference between the accounting performance of banks and their presentation of accounting irregularities under different financial reporting regimes.

3. Data and methodology

3.1 Data

Our accounting irregularities variable contains regulatory enforcement actions and class action litigation that affect publicly listed US banks. The data set is obtained by combining three sources: the SCAC, the SEC's set of AAERs and the GAO for the sample firms. In addition, balance sheet and profit and loss $(\mathrm{P} \& \mathrm{~L})$ data on the banks involved in financial misconduct between 1996 and 2014 are gathered from the Chicago Federal Reserve Call Report database.

Evidence on the empirical relationship between firm performance and the probability of accounting irregularities was gathered for this study using panel data on the listed banks for 1996-2014. Table 1 shows that the accounting irregularities identified in the SCAC, SEC's AAERs and GAO are typically egregious cases of false and misleading financial statement, material omission, misstatement and misrepresent, related party transaction, failure in loans loss reserves, reclassification, revenue restatement, expense restatement, security-related and fraud that involve GAAP violations.

In our sample, false and misleading financial statements resulting from accounting irregularities represents $45 \%$ of all samples on average for the 238 banks' event and these irregularities predominantly involve restatements. Table 1 also shows that in the 114 cases (47.9\%) of false and misleading financial statements, 57 cases (24\%) are security-related, 44 cases $(18.5 \%)$ involve restatements, 19 cases $(8 \%)$ contain material omissions, misstatements, misrepresentations and others, and four cases (1.7\%) involve fraud. 
Table 2 classifies the related regulation and acts by data source. If a firm fails to comply with the SEC's requirements, it can be placed on a list of issuers in default. As a consequence, the regulators, such as the SEC can impose a sanction. We defined five regulations and acts as a proxy for the occurrence of accounting irregularities.

Accounting irregularities affect annual reports through material manipulation, misrepresentation, or failure to disclose material fact. Specifically, a company, its subsidiary and its executives are included in the data set if it is alleged to have violated Rule 10(b)-5 of the Securities Exchange Act of 1934. An illustrative example of the SEC's justification for issuing AAERs under the fraud provisions of the Securities Exchange Act of 1934 follows: Section 10(b) of the antifraud provisions of the Securities Exchange Act of 1934 and Rule 10 b-5 thereunder proscribes the making of materially false and misleading statements in connection with the purchase or sale of any security. Table 2 also shows that in the 128 cases (53.8\%) section 10(b) and 20(a) of the Securities Exchange Act of 1934 and Rule 10 b-5, 17 cases (7.1\%) are sections 14(a) and 20(a) of the Securities Exchange Act of 1934 and Rule 14a9, 17 cases (7.1\%) involve sections 11, 12(a)(2) and 15 of the Securities Act of 1933, 17 cases (7.1\%) contain sections 22, 27, 34(b), 36(b) and 48(a) of the Securities Act of 1934 and others, and 59 cases (24.8\%) involve the Securities Exchange Act of 1933 and 1934.

Table 3 classifies case status by data source. Using the classification scheme described above, $62(26 \%)$ of the accounting irregularities are classified as dismissed, $148(62.2 \%)$ settled and $28(11.8 \%)$ as ongoing.

Figure 1 shows the change in the number of accounting irregularities by year in our sample. As shown in Figure 1, the number of accounting irregularities peaked suddenly during the postIFRS period and 2007-2008 global financial crisis and although they dropped thereafter, they were still well above the levels of the late 2014 by the end of the sample period. 
Figure 2 shows the changes in total money amount by year if accounting irregularities are calculated using the cases to which regulators assigned a monetary penalty. As shown in Figure 2 , the total monetary penalty amount peaked suddenly in 2001 during the both post-IFRS period and during the 2007-2008 global financial crisis.

\subsection{Methodology}

We use alternative proxies to measure of accounting irregularities an indicator of the quality of financial accounting disclosures (IFRS or local GAAP) in the USA. We use an indicator variable for whether fraudulent and non-fraudulent US banks have better accounting standards than the median. The following logit model is estimated using these firms' financial ratios to see which are related to accounting irregularities (Spathis, 2002). The variable names, abbreviations, and descriptions are provided in Appendix Table A1. We engage a firm collected logit model to estimate the likelihood of corporate misreporting having been committed in terms of accounting irregularities, which is as follows:

Accounting irregularities $=\beta_{0}+\beta_{1}$ ROAit $+\beta_{2}$ ERit $+\beta_{3}$ NOITAit $+\beta_{4}$ CARit $+\beta_{5}$ NIMit + $\beta_{6}$ LRit $+\beta_{7}$ ASSETSit + eit

where accounting irregularities is a dummy variable indicating the presence of misreporting. The remaining independent variables are commonly used to estimates corporate misreporting in the literature. They are the bank-specific financial statement variables, including return on assets, $\left(\mathrm{ROA}_{\mathrm{it}}\right)$, efficiency ratio, $\left(\mathrm{ER}_{\mathrm{it}}\right)$, asset quality (net operating income to total assets), (NOITA $\left.A_{i t}\right)$, capital-asset ratio, $\left(\mathrm{CAR}_{\mathrm{it}}\right)$, net interest margin ratio, $\left(\mathrm{NIM}_{\mathrm{it}}\right)$, loans ratio, $\left(\mathrm{LR}_{\mathrm{it}}\right)$, and bank size, $\left(\right.$ ASSETS $\left._{i t}\right)$.

A company and its executives face serious penalties imposed by the SEC and other authorities when accounting irregularities occur and they fail to follow accounting standards requirements. For example, the maximum penalties imposed on a corporation or its executives for violating 
the regulations are as follows, the SCAC bank case $\$ 375 \mathrm{~m}$, SEC bank case $\$ 200 \mathrm{~m}$, and GAO bank case $\$ 824 \mathrm{~m}$. These figures show the serious penalties for accounting irregularities. Because of this trend, we expect criminal action to have played a significant role in the regulator's response to accounting irregularities. The question we pose is whether a change in bank performance increases or decreases the bank-level penalties in our sample. We use the variable of banking performance during accounting irregularities measured as the logarithm of the amount of civil monetary penalties. To analyze whether the relationship between monetary penalties and accounting irregularities depends on a securities-related class-action being filed against firms, we estimate the following ordinary least squares (OLS) regression model following Collins et al. (2008).

Monetary Penalty $=\beta_{0}+\beta_{1}$ ROAit $+\beta_{2}$ ERit $+\beta_{3}$ NOITAit $+\beta_{4}$ CARit $+\beta_{5}$ NIMit + $\beta_{6}$ LRit $+\beta_{7}$ ASSETSit $+\varepsilon$ it

where monetary penalty is the dummy variable indicating the presence of misreporting.

Excessive risk-taking and misconduct by financial executives in the previous decade contributed to the 2008 global financial crisis. In response to this crisis, in July 2010, congress approved the Dodd-Frank Act (also known as the Dodd-Frank Wall Street Reform and Consumer Protection Act), which required several regulators to institute reforms to increase financial stability (Arena and Nguyen, 2019). The Dodd-Frank Act, the most widespread financial reform in the USA, regulates the financial industry and protects consumers to avoid a repeat of the global financial crisis (https://searchfinancialsecurity.techtarget.com /definition/Dodd-Frank-Act, accessed, 23 August 2019). Therefore, we also adopt a firm collected logit model to estimate the likelihood the Dodd-Frank Act affected accounting irregularities, which is as follows: 
Accounting Irregularities $=\beta_{0}+\beta_{1}$ ROAit $+\beta_{2}$ ERit $+\beta_{3}$ NOITAit $+\beta_{4}$ CARit +

$\beta_{5}$ NIMit $+\beta_{6}$ LRit $+\beta_{7}$ ASSETSit $+\beta_{8}$ DODD - FRANKit $+\varepsilon i t$

where accounting irregularities is the dummy variable indicating the presence of misreporting.

4. Empirical results

\subsection{Descriptive statistics}

Table 4 summarizes the descriptive statistics. The table contains data on accounting irregularities from 1996 to 2014. We examine whether accounting standards stimulate financial misconduct by estimating a logit regression model to assess whether the value of accounting information has changed. The descriptive statistics of the sample banks in Table 4 provides the details of the sample reporting under US GAAP and IFRS. 30\% of the sample represents the fraudulent banks sample. On the contrary, $70 \%$ of sample is from the non-fraudulent banks. Table 4 shows a positive bank performance result by considering ROA and NOITA. According to the Table 4, ROA has a mean value of 0.84 with minimum and maximum values of -14.738 and 14.991, respectively. The average of NOITA is 0.842 with minimum and maximum values of -8.768 and 14.966 , respectively. The average LR is $51.6 \%$ of the total assets. Table 4 also shows positive results of ER and CR; they have a mean value about $66 \%$ and $11 \%$, respectively.

Table 5 shows the univariate analysis of sample by comparing the US GAAP and IFRS groups. 93.7\% of US banks in the sample uses US GAAP. shows that accounting irregularities constitutes $93.7 \%$ of the US GAAP. $6.3 \%$ of the sample is classified in the IFRS sample. With the exceptions of ER and ASSETS, the means of the variables in the US GAAP group is greater than the IFRS group.

These results provide less statistically significant evidence of comparison between two groups; the two-sample t-test results show that the means of NIM and ASSETS are significantly different in US GAAP and IFRS groups. Similarly, Kohlbeck and Warfield (2010) report 
similar results in investigation of the effect of accounting standards on earnings management. In addition, although banks in IFRS group have lower profitability with ROA in the sample period, the mean profitability of US GAAP banks increases overall. This result is in line with the study of Defond and Jiambalvo (1994); they find that the profitability is triggered by the accounting irregularities.

Table 6 shows that the two-sample t-test of equal variances in the sample period differs between fraudulent and non-fraudulent banks. Non-fraudulent banks have higher ROA, cost efficiency (ER), NOITA and NIM than fraudulent banks. By contrast, the other variables in our sample are likely less in the fraudulent banks group than in the non-fraudulent bank group. In addition, we find a significant difference between the non-fraudulent and fraudulent groups for profitability ratios. For this test, the mean of the non-fraudulent group

is higher than that of the fraudulent group in the United States.

\subsection{Regression findings}

Table 7 shows the estimates of the logit model. We find that a significant effect for accounting irregularities only appears for CAR, NIM and ASSETS in the long-term estimates, while there are significant effects of ROA, NOITA and CAR in the pre-IFRS adoption period. Our results suggest that ROA and NOITA have significant and positive effects on the likelihood of accounting irregularities after the implementation of mandatory IFRS in 2005 . In line with the results of all sample, an increased size of the banks declines the likelihood of accounting irregularities in the sample. Before the global financial crisis, the relatively higher operating expenses significantly declines the likelihood of accounting irregularities. This significant effect of ER disappears in the post period of the crisis. The size variable has negative and significant effect on the likelihood except for post-IFRS period. This result is consistent with 
that of Eleyan et al. (2008), who suggest that our sample firms are less likely to be involved in these accounting irregularities.

Table 8 shows the estimates of the OLS regression model. We find significant effect of some bank performance measures on the monetary penalties in all sample. Higher ROA and NIM lead lower monetary penalties while higher NOITA lead higher monetary penalties. We detect the same effect of these measures on the level of monetary penalties after the adaptation of IFRS in 2005. The relative decline in the coefficient of NOITA and the relative increase in the coefficients of ROA and NIM in the post-IFRS period indicates that the lesser effect on the level of monetary penalties. On the contrary, the significant effect of these measures disappears in the pre-IFRS period. By this, we do not detect significant monetary penalties to be imposed on managers for violating GAAP consistent with Desai et al. (2006). Our results are also consistent with those of Srinivasan et al. (2015), who find that the lower frequency of accounting irregularities in the financial statements implies fewer ex post penalties. Desai et al. (2006) findings suggest that private monetary penalties for GAAP violations are severe as partial substitutes for violating GAAP, and thus may reduce the cost of enforcement. Similarly, Collins et al.'s (2008) findings suggest that monetary penalties on executives for decreasing earnings restatements are related to the presence of class-action securities litigation.

Table 9 shows the estimate of the logit model by considering the impact of the Dodd-Frank Act. We find significant effects of ROA and NOITA at the \%10 level and CAR and ASSETS at the $1 \%$ level on the likelihood of accounting irregularities in the long-term estimates while the significance of CAR disappears in the post-IFRS adoption period. Our results suggest that the Dodd-Frank Act has a significant and positive effect on the likelihood of accounting irregularities while the results are in line with the results in post-IFRS period in Table 7 . The plausible justification points out the implementation of mandatory IFRS in 2005 seems to have influenced the US banking industry under the Dodd-Frank Act by involving the same type of 
corporate misconduct as the irregularities banks involve. Moreover, only ASSETS and DoddFrank show a significant effect at the $1 \%$ level with the increases in the post-global financial crisis period suggesting a greater likelihood that accounting irregularities will be revealed. Our results are also consistent with those of Arena and Nguyen (2019), who show that litigation risk declined significantly after the Dodd-Frank Act. In addition, in these estimates, bank size plays a crucial role in mitigating the impact of accounting irregularities.

\section{Conclusions}

Accounting irregularities involving financial statements are a serious threat to market participants' confidence in financial information. Misreporting financial statement weakens a firm's control structure and lowers the quality of its audit functions. Thus, it might become a doubtful company for financial information users and the public which will have less confidence its financial reporting outcomes. Our results show that banks adopting US GAAP have better operating performance than fraudulent banks in the IFRS group except for certain variables. However, there is little statistically significant evidence of an association between accounting irregularities and accounting standards. Our results are also consistent with the survey by Kohlbeck and Warfield (2010) which shows that accounting standards are linked to fewer accounting irregularities. Similarly, our results are consistent with those of Collins et al. (2008), Desai et al. (2006) and Srinivasan et al. (2015), who suggest that monetary penalties to executives decrease accounting irregularities in financial statements.

We find that significant effects on the accounting irregularities characteristics are ROA and NOITA as well as for CAR and ASSETS in the long term estimates, while there exists insignificant effects of ER, CAR, NIM, and LR in the post- IFRS adoption by considering the negative and significant effect of Dodd-Frank Act on the likelihood of accounting irregularities. 
References

Agrawal, A. and Chadha, S. (2005), "Corporate governance and accounting scandals", The Journal of Law and Economics, Vol. 48 No. 2, pp. 371-406.

Altunbas, Y., Thornton, J. and Uymaz, Y. (2018), "CEO tenure and corporate misconduct: evidence from US banks”, Finance Research Letters, Vol. 26, pp. 1-8.

Amiram, D., Bozanic, Z., Cox, J.D., Dupont, Q., Karpoff, J.M. and Sloan, R. (2018), “Financial reporting fraud and other forms ofmisconduct: a multidisciplinary review of the literature", Review of Accounting Studies, Vol. 23 No. 2, pp. 732-783.

Anderson, R., Mansi, S. and Reeb, D. (2004), "Board characteristics, accounting report integrity, and the cost of debt", Journal of Accounting and Economics, Vol. 37 No. 3, pp. 315-342.

Arena, M.P. and Nguyen, N.Q. (2019), “Compensation clawback policies and corporate lawsuits”, Journal of Financial Regulation and Compliance, Vol. 27 No. 1, pp. 70-85.

Armstrong, C.S., Ittner, C.D. and Larcker, D.F. (2009), “ Economic characteristics, corporate governance, and the influence of compensation consultants on executive pay levels", Working paper, available at: http://ssrn.com/abstract=1145548

Armstrong, C.S., Jagolinzer, A.D. and Larcker, D.F. (2010), “Chief executive officer equity incentives and accounting irregularities", Journal of Accounting Research, Vol. 48 No. 2, pp. 225-271.

Baber, W.R., Kang, S.-H., Liang, L. and Zhu, Z. (2009), "Shareholder rights, corporate governance, and accounting restatement”, Working paper, Georgetown University, available at: http://ssrn.com/abstract=760324.

Barth, M.E., Landsman, W.R., Lang, M.H. and Williams, C. (2012), “Are IFRS-based and U.S. GAAP based accounting amounts comparable?", Journal of Accounting and Economics, Vol. 54 No. 1, pp. 68-93.

Black, W.K. (2005), "Control frauds" as financial super-predators: how 'pathogens' make financial markets inefficient”, The Journal of Socio-Economics , Vol. 34 No. 6, pp. 734-755.

Bolton, R.J. and Hand, D.J. (2002), “Statictical fraud detection: a review”, Statistical Science, Vol. 17 No. 3, pp. 235-249.

Burns, N. and Kedia, S. (2008), "Executive option exercises and financial misreporting", Journal of Banking and Finance, Vol. 32, pp. 845-857. 
Coffee, J.C. (2005), “A theory of corporate scandals: why the USA and Europe differ”, Oxford Review of Economic Policy, Vol. 21 No. 2, pp. 198-211.

Collins, D., Reitenga, A.L. and Sanchez, J.M. (2008), “The impact of accounting restatements on CFO turnover and bonus compensation: does securities litigation matter?", advances in accounting incorporating", Advances in Accounting, Vol. 24 No. 2, pp. 162-171.

Core, J.E. (2010), "Discussion of chief executive officer equity incentives and accounting irregularities", Journal of Accounting Research, Vol. 48 No. 2, pp. 273-287.

Dechow, P.M., Sloan, R.G. and Sweeney, A.P. (1996), "Causes and consequences of earnings manipulation: an analysis of firms subject to enforcement action by the SEC", Contemporary Accounting Research, Vol. 13 No. 1, pp. 1-36.

DeFond, M.L. and Jiambalvo, J. (1994), "Debt covenant violation and manipulation of accruals", Journal of Accounting and Economics, Vol. 17 Nos 1/2, pp. 145-176.

Desai, H., Hogan, C.E. andWilkins, M.S. (2006), "The reputational penalty for aggressive accounting: earnings restatements andmanagement turnover", TheAccounting Review, Vol. 81No. 1, pp. 83-112.

Donelson, D.C., McInnis, J.M. and Mergenthaler, R.D. (2012), "Rules-based accounting standards and litigation”, The Accounting Review, Vol. 87 No. 4, pp. 1247-1279.

Efendi, J., Srivastava, A. and Swanson, E.P. (2007), "Why do corporate managers misstate financial statements? The role of option compensation and other factors", Journal of Financial Economics, Vol. 85 No. 3, pp. 667-708.

Elayan, F.A., Li, J. and Meyer, T.O. (2008), "Accounting irregularities, management compensation structure and information asymmetry", Accounting and Finance, Vol. 48, pp. 741-760.

El-Gazzar, S.M. and Finn, P.M. (2017), "Restatements and accounting quality: a comparison between IFRS and US-GAAP”, Journal of Financial Reporting and Accounting, Vol. 15 No. 1 , pp. 39-58.

Erickson, M., Hanlon, M. and Maydew, E.L. (2006), "Is there a link between executive equity incentives and accounting fraud?", Journal of Accounting Research, Vol. 44 No. 1, pp. 113-143.

Fich, E.M. and Shivdasani, A. (2007), "Financial fraud, director reputation, and shareholder wealth”, Journal of Financial Economics, Vol. 86 No. 2, pp. 306-336.

Frost, C., Henry, E. and Lin, S. (2009), "Response to the SEC's proposed rule-Roadmap for the potential use of financial statements prepared in accordance with international 
financial reporting standards (IFRS) by US", Journal of International Accounting Research", , Vol. 8 No. 2, pp. 61-85.

General Accounting Office (2002), "Financial statement restatements: trends, market impacts, regulatory responses, and remaining challenges, report to the chairman, committee on banking, housing, and urban affairs", US Senate GAO-03-138.

Hail, L., Leuz, C. and Wysocki, P. (2010), "Global accounting convergence and the potential adoption of IFRS by the U.S. (part I): conceptual underpinnings and economic analysis", Accounting Horizons, Vol. 24 No. 3, pp. 355-394.

Harris, J. and Bromiley, P. (2007), "Incentives to cheat: the influence of executive compensation and firm performance on financial misrepresentation", Organization Science, Vol. 18 No. 3, pp. 350-367.

Hefendehl, R. (2004), "Enron, WorldCom, and the consequences: Business criminal law between doctrinal requirements and the hopes of crime policy", Buffalo Criminal Law Review, Vol. 8 No. 1, pp. 51-88. available at: https://searchfinancialsecurity.techtarget.com/definition/Dodd-Frank-Act (accessesd 23 August 2019).

Jayaraman, S. and Milbourn, T. (2015), “CEO equity incentives and financial misreporting: the role of auditor expertise", The Accounting Review, Vol. 90 No. 1, pp. 321-350.

Johnson, M.F., Nelson, K.K. and Pritchard, A.C. (2007), "Do the merits matter more? The impact of the private securities litigation reform act", Journal of Law, Economics, and Organization, Vol. 23 No. 3, pp. 627-652.

Johnson, S.A., Ryan, jr. H.E. and Tian, Y.S. (2009), "Managerial incentives and corporate fraud: the sources of incentives matter", Review of Finance, Vol. 13 No. 1, pp. 115145.

Judge, W., Li, S. and Pinsker, R. (2010), "National adoption of international accounting standards-an institutional perspective", Corporate Governance: An International Review, Vol. 18 No. 3, pp. 161-174.

Kohlbeck, M. and Warfield, T. (2010), “Accounting standard attributes and accounting quality: discussion and analysis", Research in Accounting Regulation, Vol. 22 No. 2, pp. 5970.

Kothari, S., Ramanna, K. and Skinner, D. (2010), "Implications for GAAP from an analysis of positive research in accounting", Journal of Accounting and Economics, Vol. 50 Nos 2/3, pp. 246-286. 
Larcker, D.F. and Tayan, B. (2010), “Financial manipulation: words don't lie”, Stanford Closer Look Series, July 23, 2010, pp. 1-5.

Larcker, D.F., Richardson, S.A. and Tuna, I. (2007), “Corporate governance, accounting outcomes, and organizational performance", The Accounting Review, Vol. 82 No. 4, pp. 963-1008.

Law, P. (2011), “Corporate governance and no fraud occurrence in organizations”, Managerial Auditing Journal, Vol. 26 No. 6, pp. 501-518.

Murphy, D.L., Shrieves, R.E. and Tibbs, S.L. (2009), "Understanding the penalties associated with corporate misconduct: an empirical examination of earnings and risk", Journal of Financial and Quantitative Analysis, Vol. 44 No. 1, pp. 55-83.

Nisbett, A. and Sheikh, A. (2007), “Accounting scandals: does 'rules vs principles' matter?”, TN CPA Journal Nov.2007, pp. 10-12.

Nobes, C. and Parker, R. (2008), Comparative International Accounting, 10th ed., Prentice Hall-Financial Times, Harlow.

O’Connor, J.P., Priem, R.L., Coombs, J.E. and Gilley, K.M. (2006), “Do CEO stock options prevent or promote fraudulent financial reporting?", Academy of Management Journal, Vol. 49 No. 3, pp. 483-500.

Pai, P.F., Hsu, M.-F. and Wang, M.-C. (2011), "A support vector machine-based model for detecting top management fraud”, Knowledge-Based Systems, Vol. 24 No. 2, pp. 314321.

Palmrose, Z.V., Richardson, V.J. and Scholz, S. (2004), "Determinant of market reactions to restatement announcements", Journal of Accounting and Economics, Vol. 37 No. 1, pp. 59-89.

Pelucio-Grecco, M.C., Geron, C.M.S., Grecco, G.B. and João Lima, J.P.C. (2014), “The effect of IFRS on earnings management in Brazilian non-financial public companies", Emerging Markets Review, Vol. 21, pp. 42-66.

Peng, L. and Röell, A. (2008), "Executive pay and shareholder litigation”, Review of Finance, Vol. 12 No. 1, pp. 141-184.

Perols, J.L. and Lougee, B.A. (2011), "The relation between earnings management and financial statement fraud", Advances in Accounting, Vol. 27 No. 1, pp. 39-53.

Petersen, C.V. and Plenborg, T. (2012), Financial Statement Analysis: Valuation, Credit Analysis, Ececutive Compensation, Financial Times Prentice Hall, Harlow.

Rankin, M., Stanton, P., McGowan, S., Ferlauto, K. and Tilling, M. (2012), Contemporary Issues in Accounting, John Wiley\&Sons Ltd. 
Richardson, S. Tuna, I. and Wu, M. (2002), "Predicting earnings management: the case of earnings restatements", available at: http://ssrn.com/abstract=338681

Smaili, N. and Labelle, R. (2015), "Corporate governance and accounting irregularities: Canadian evidence", Journal of Management Governance, doi: 10.1007/s10997-0159314-4.

Spathis, C.T. (2002), "Detecting false financial statements using published data: some evidence from Greece”, Managerial Auditing Journal, Vol. 17 No. 4, pp. 179-191.

Srinivasan, S., Wahid, A.S. and Yu, G. (2015), “Admitting mistakes: home country effect on the reliability of restatement reporting", The Accounting Review, Vol. 90 No. 3, pp. 1201-1240.

Ugrin, J.C., Mason, T.W. and Emley, A. (2017), “Culture's consequence: the relationship between income-increasing earnings management and IAS/IFRS adoption across cultures", Advances in Accounting, Vol. 37, pp. 140-151.

Uzun, H., Szewczyk, S.H. and Varma, R. (2004), "Board composition and corporate fraud", Financial Analysts Journal, Vol. 60 No. 3, pp. 33-43.

Wang, C. (2014), “Accounting standards harmonization and financial statement comparability: evidence from transnational information transfer", Journal of Accounting Research, Vol. 52 No. 4, pp. 955-992.

Wang, Y. and Campbell, M. (2012), “Corporate governance, earnings management, and IFRS: empirical evidence from Chinese domestically listed companies", Advances in Accounting, Vol. 28 No. 1, pp. 189-192.

Warren, D., Zey, M., Granston, T. and Roy, J. (2011), "Earnings fraud: Board control vs CEO control and corporate performance _1992-2004”, Managerial and Decision Economics, Vol. 32 No. 1, pp. 17-34.

Zahra, S.A., Priem, R.L. and Rasheed, A.A. (2007), "Understanding the causes and effects of top management fraud”, Organizational Dynamics, Vol. 36 No. 2, pp. 122-139.

Zhao, Y. and Chen, K.H. (2008), "Staggered boards and earnings management", The Accounting Review, Vol. 83 No. 5, pp. 1347-1381. 
Figure 1: Change in the number of accounting irregularities by years

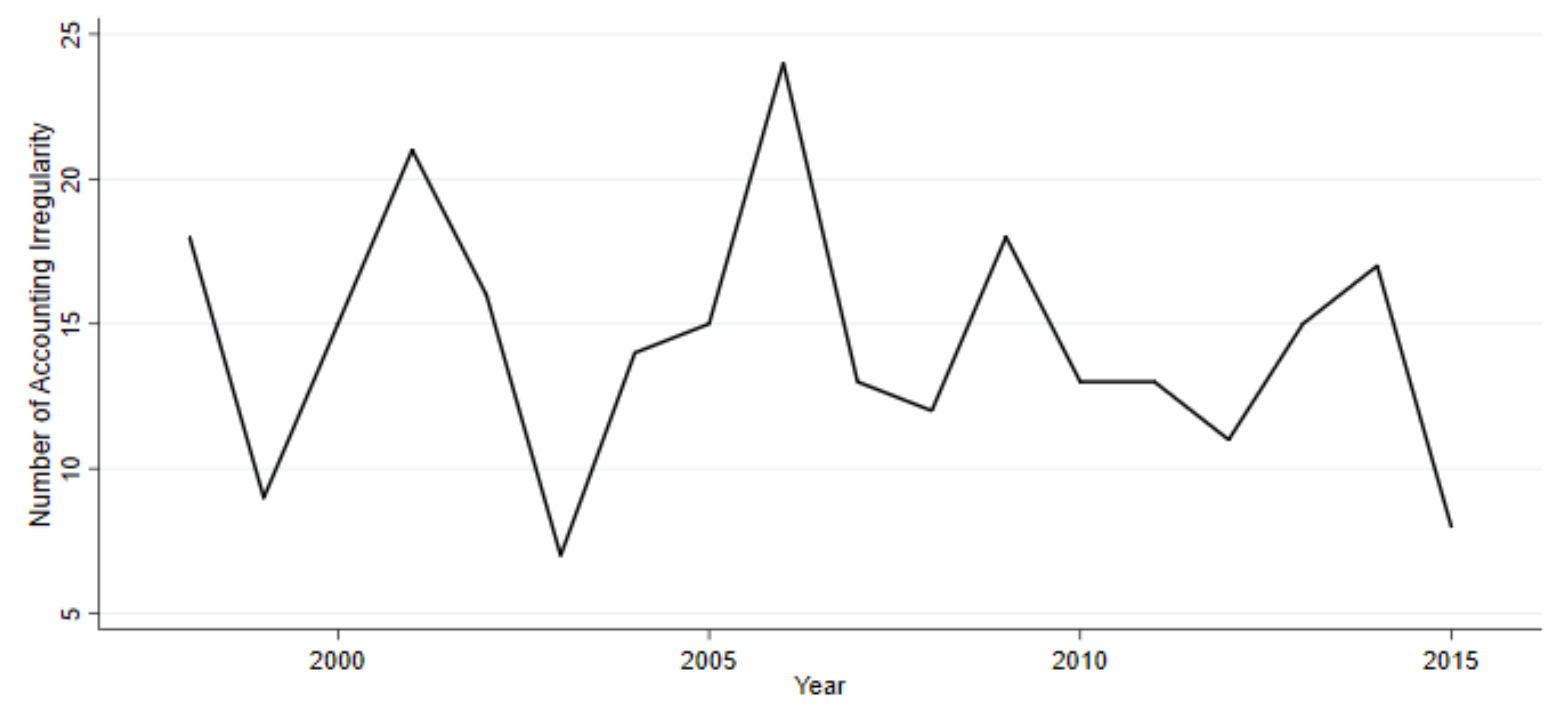

Figure 2: Change in total money penalty amount by year

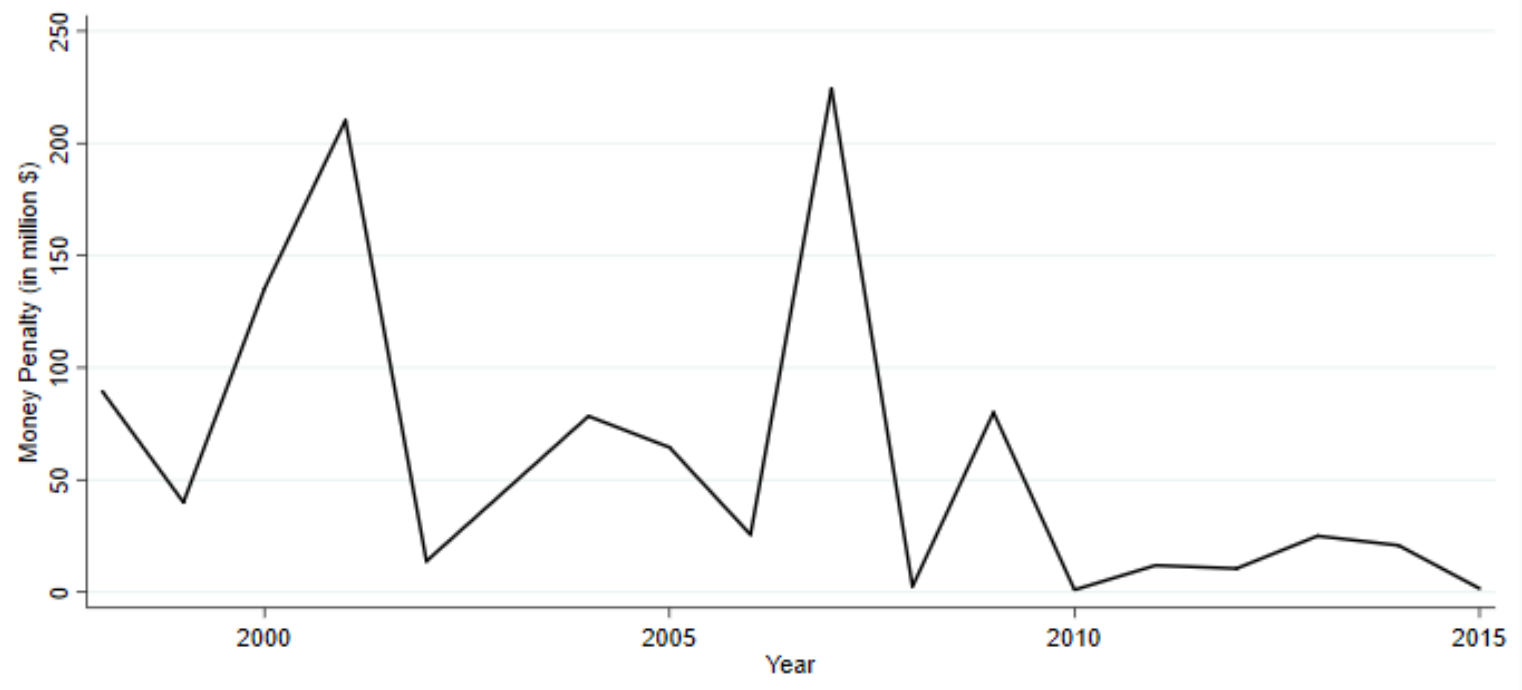


Table 1. Classification and number of accounting irregularities in publicly listed US banks

\begin{tabular}{|c|c|c|c|c|}
\hline & \multicolumn{4}{|c|}{ Data sources } \\
\hline & SCAC & SEC & $\mathrm{GAO}$ & Total \\
\hline False and misleading financial statement & 102 & 12 & & 114 \\
\hline Material omission and misstatement, misrepresentation & 14 & & & 14 \\
\hline Failure to disclose information & 3 & & & 3 \\
\hline Related party transaction & & & 1 & 1 \\
\hline Failed to loans loss reserves & 1 & & & 1 \\
\hline Reclassification & & & 14 & 14 \\
\hline Revenue restatement (overstated income, reduce earnings or misreported revenue) & 7 & 2 & 5 & 14 \\
\hline Expense restatement (cost and expense, restructuring, assets or inventory) & & & 16 & 16 \\
\hline $\begin{array}{l}\text { Security-related (including merger and acquisition transactions; derivates and hedge } \\
\text { funds and others) }\end{array}$ & 37 & 5 & 15 & 57 \\
\hline $\begin{array}{l}\text { Fraud (including securities, massive, mail, wire, services, common law and } \\
\text { constructive fraud) }\end{array}$ & 4 & & & 4 \\
\hline Total & 168 & 19 & 51 & 238 \\
\hline $\begin{array}{l}\text { Note: SCAC: Securities Class Action Clearinghouse; AAERs: Accounting and Auditing } \\
\text { Accounting Office; We use the definition of accounting irregularities suggested by the Gen } \\
\text { It defines accounting irregularities as including aggressive accounting practices, internat } \\
\text { applied to financial statements because financial statements were not fairly pres } \\
\text { misinterpretation of accounting rules, and fraud. Our sample is obtained above as follov } \\
\text { firms disclosed accounting irregularities due to a misapplication of accounting standards }\end{array}$ & aforceme & $\begin{array}{l}\text { Relea } \\
\text { ng Offic }\end{array}$ & (2002) & $\begin{array}{l}\text { Seneral } \\
\text { the US. } \\
\text { f facts; } \\
\text { uld be } \\
\text { where }\end{array}$ \\
\hline
\end{tabular}

Table 2. Classification of related regulation and act

\begin{tabular}{|c|c|c|c|c|}
\hline & \multicolumn{4}{|c|}{ Data sources } \\
\hline & SCAC & SEC & GAO & Total \\
\hline Section 10(b) and 20(a) of the Securities Exchange Act of 1934 and Rule 10 b-5 83 & 83 & 7 & 38 & 128 \\
\hline Sections 14(a) and 20(a) of the Securities Exchange Act of 1934 and Rule 14a-9 & 7 & 10 & & 17 \\
\hline Sections $11,12(a)(2)$ and 15 of the Securities Act of 1933 & 15 & 2 & & 17 \\
\hline Sections 22, 27, 34(b), 36(b) and 48(a) of the Securities Act of 1934 & 4 & & 13 & 17 \\
\hline The Securities Exchange Act of 1933 and 1934 & 59 & & & 59 \\
\hline Total & 168 & 19 & 51 & 238 \\
\hline
\end{tabular}

Table 3. Classification of cases status

\begin{tabular}{lcccc}
\hline & \multicolumn{2}{c}{ Data sources } \\
\cline { 2 - 5 } & SCAC & SEC & GAO & Total \\
\hline Dismissed & 62 & & & 62 \\
Settled & 78 & 19 & 51 & 148 \\
Ongoing & 28 & & & 28 \\
Total & 168 & 19 & 51 & 238 \\
\hline
\end{tabular}


Table 4. Descriptive statistics for fraudulent and non-fraudulent banks

\begin{tabular}{lcccccc}
\hline & $\mathrm{N}$ & Mean & Median & Std. Dev. & Minimum & Maximum \\
\hline ROA & 14276 & 0.836 & 0.957 & 1.257 & -14.738 & 14.991 \\
ER & 13524 & 65.738 & 65.469 & 13.571 & 4.398 & 99.990 \\
NOITA & 14260 & 0.842 & 0.945 & 1.123 & -8.768 & 14.966 \\
CAR & 14291 & 10.942 & 9.438 & 6.940 & -3.217 & 100.000 \\
NIM & 14292 & 3.962 & 3.958 & 1.153 & 0.089 & 19.815 \\
LR & 5258 & 0.516 & 0.193 & 0.990 & -1.371 & 13.253 \\
ASSETS & 14310 & 12.426 & 11.835 & 2.295 & 5.557 & 21.453 \\
\hline
\end{tabular}

Table 5. Two-sample t-test equal variances for accounting standards

\begin{tabular}{|c|c|c|c|c|c|c|c|}
\hline & \multirow[b]{2}{*}{$\mathrm{N}$} & \multicolumn{2}{|c|}{ US GAAP } & \multicolumn{3}{|c|}{ IFRS } & \multirow[b]{2}{*}{ t score } \\
\hline & & Mean & Std. Dev. & $\mathrm{N}$ & Mean & Std. Dev. & \\
\hline ROA & 13106 & 0.838 & 1.275 & 1170 & 0.815 & 1.029 & 0.616 \\
\hline ER & 12399 & 65.73 & 13.49 & 1125 & 65.84 & 14.43 & -0.253 \\
\hline NOITA & 13090 & 0.846 & 1.134 & 1170 & 0.795 & 0.998 & 1.492 \\
\hline CAR & 13121 & 10.95 & 7.061 & 1170 & 10.81 & 5.408 & 0.673 \\
\hline NIM & 13122 & 3.971 & 1.169 & 1170 & 3.861 & 0.952 & $3.136 * * *$ \\
\hline LR & 4798 & 0.521 & 1.003 & 460 & 0.464 & 0.846 & 1.191 \\
\hline ASSETS & 13140 & 12.38 & 2.240 & 1170 & 12.96 & 2.783 & $-8.376^{* * *}$ \\
\hline
\end{tabular}

Note: This table reports the comparison of means of banks that use US GAAP and IFRS. ***, **, * indicate statistical significance of t-test at the $1 \%, 5 \%$, and $10 \%$ levels respectively.

Table 6. Two-sample t-test equal variances for non-fraudulent and fraudulent banks

\begin{tabular}{lccccccc}
\hline & \multicolumn{3}{c}{ Non-fraudulent banks } & \multicolumn{5}{c}{ Fraudulent banks } \\
& $\mathrm{N}$ & Mean & Std. Dev. & $\mathrm{N}$ & Mean & Std. Dev. & $\mathrm{t}$ score \\
\hline ROA & 10024 & 0.979 & 0.840 & 4252 & 0.501 & 1.866 & $21.09^{* * * *}$ \\
ER & 9746 & 66.63 & 13.04 & 3778 & 63.44 & 14.59 & $12.32^{* * * *}$ \\
NOITA & 10023 & 0.959 & 0.826 & 4237 & 0.565 & 1.588 & $19.39^{* * *}$ \\
CAR & 10026 & 11.06 & 4.652 & 4265 & 10.67 & 10.51 & $3.109^{* * *}$ \\
NIM & 10026 & 4.030 & 0.952 & 4266 & 3.802 & 1.512 & $10.89^{* * *}$ \\
LR & 3899 & 0.328 & 0.588 & 1359 & 1.056 & 1.552 & $-24.64^{* * *}$ \\
ASSETS & 10026 & 11.63 & 1.203 & 4284 & 14.29 & 3.039 & $-75.16^{* * *}$ \\
\hline
\end{tabular}

Note: This table reports the comparison of means of non-fraudulent and fraudulent banks. ***, **,* indicate statistical significance of t-test at the $1 \%, 5 \%$, and $10 \%$ levels respectively. 
Table 7. Logit estimates of likelihood of accounting irregularities by US banks

\begin{tabular}{|c|c|c|c|c|c|}
\hline & \multicolumn{3}{|c|}{ Panel A: Pre and post IFRS adoption period } & \multicolumn{2}{|c|}{ Panel B: Global financial crisis period } \\
\hline & All sample & Before 2005 & After 2005 & Before 2008 & After 2008 \\
\hline ROA & $-0.166(0.121)$ & $1.561 *(0.948)$ & $-0.491 *(0.269)$ & $0.126(0.257)$ & $-0.892(0.621)$ \\
\hline ER & $-0.001(0.001)$ & $-0.005(0.005)$ & $-0.001(0.001)$ & $-0.008 * *(0.003)$ & $-0.001(0.001)$ \\
\hline NOITA & $0.192(0.119)$ & $-1.756 *(0.954)$ & $0.604 * *(0.268)$ & $-0.112(0.255)$ & $0.888(0.613)$ \\
\hline CAR & $0.031 * *(0.013)$ & $0.159 * * *(0.042)$ & $0.024(0.022)$ & $0.031(0.026)$ & $0.05(0.052)$ \\
\hline NIM & $-0.123 * *(0.059)$ & $-0.291(0.194)$ & $-0.120(0.095)$ & $-0.078(0.104)$ & $-0.104(0.174)$ \\
\hline LR & $0.016(0.059)$ & $-0.188(0.272)$ & $0.034(0.084)$ & $-0.002(0.115)$ & $-0.17(0.149)$ \\
\hline ASSETS & $-0.056 * * *(0.020)$ & $-0.002(0.076)$ & $-0.120 * * *(0.031)$ & $-0.101 * *(0.041)$ & $-0.182 * * *(0.056)$ \\
\hline _cons & $0.798(0.459)$ & $-3.029(1.852)$ & $3.166 * * *(0.733)$ & $0.435(1.005)$ & $5.115 * * *(1.466)$ \\
\hline Observations & 1359 & 604 & 755 & 843 & 516 \\
\hline Log likelihood & -922.83 & -110.26 & -404.43 & -323.21 & -168.02 \\
\hline Pseudo R2 & 0.016 & 0.124 & 0.043 & 0.029 & 0.094 \\
\hline
\end{tabular}

Note: Logit estimates of likelihood of accounting irregularities by US banks are defined in Table 7. This table reports the impacts of the explanatory of bank financial variables and standard errors are reported in parentheses. ***, **, and * indicate statistical significance at the $1 \%, 5 \%$ and $10 \%$ levels, respectively.

Table 8. OLS estimates of likelihood of monetary penalties by US banks

\begin{tabular}{lccccc}
\hline & \multicolumn{2}{c}{ Panel A: Pre and post IFRS adoption period } & \multicolumn{2}{c}{ Panel B: Global financial crisis period } \\
& All sample & Before 2005 & After 2005 & Before 2008 & After 2008 \\
\hline ROA & $-3.337 * * *(0.958)$ & $0.952(2.337)$ & $-2.889 * *(1.049)$ & $0.001(0.021)$ & $-0.076(0.063)$ \\
ER & $-0.001(0.001)$ & $-0.001(0.003)$ & $-0.001(0.001)$ & $-0.001(0.001)$ & $-0.001(0.001)$ \\
NOITA & $3.370 * * *(0.965)$ & $-0.093(0.145)$ & $2.940 * * *(1.052)$ & $-0.065(0.074)$ & $0.051^{*}(0.028)$ \\
CAR & $0.009(0.012)$ & $0.008(0.102)$ & $0.017(0.015)$ & $0.001(0.031)$ & $0.137(0.104)$ \\
NIM & $-1.238 * *(0.380)$ & $-2.219(1.298)$ & $-1.069 * *(0.433)$ & $-0.474(0.951)$ & $-1.113 *(0.586)$ \\
LR & $0.039(0.113)$ & $0.125(0.693)$ & $0.101(0.114)$ & $-0.311(0.726)$ & $0.113(0.218)$ \\
ASSETS & $-0.474(0.302)$ & $-1.050(2.919)$ & $-0.282(0.194)$ & $1.770(1.757)$ & $-0.381(0.452)$ \\
cons & $13.412 * * *(1.327)$ & $15.328 * *(4.315)$ & $13.325 * * *(1.601)$ & $11.106 * *(3.852)$ & $14.575 * * *(2.270)$ \\
Observations & 206 & 72 & 134 & 113 & 9.445 \\
R2 & 0.493 & 0.421 & 0.539 & 0.567 \\
\hline
\end{tabular}

Note: OLS estimates of likelihood of monetary penalties by US banks are defined in Table 8 . This table reports the impacts of the explanatory of bank financial variables and standard errors are reported in parentheses. ***, **, and * indicate statistical significance at the $1 \%, 5 \%$, and $10 \%$ levels, respectively. 
Table 9. Logit estimates of likelihood of Dodd-Frank act by US banks

\begin{tabular}{lccccc}
\hline & \multicolumn{2}{c}{ Panel A: Pre and post IFRS adoption period } & \multicolumn{2}{c}{ Panel B: Global financial crisis period } \\
& All sample & Before 2005 & After 2005 & Before 2008 & After 2008 \\
\hline ROA & $-0.257^{*}(0.155)$ & $1.561^{*}(0.948)$ & $-0.636^{* *}(0.294)$ & $0.126(0.257)$ & $-0.983(0.675)$ \\
ER & $-0.001(0.001)$ & $-0.005(0.005)$ & $-0.001(0.001)$ & $-0.008^{* *}(0.003)$ & $-0.001(0.001)$ \\
NOITA & $0.282^{*}(0.151)$ & $-1.756^{*}(0.954)$ & $0.746^{* *}(0.294)$ & $-0.112(0.255)$ & $0.957(0.671)$ \\
CAR & $0.054^{* * *(0.018)}$ & $0.159^{* * *(0.042)}$ & $0.036(0.025)$ & $0.031(0.026)$ & $0.058(0.053)$ \\
NIM & $-0.060(0.075)$ & $-0.291(0.194)$ & $-0.042(0.106)$ & $-0.078(0.104)$ & $-0.067(0.180)$ \\
LR & $-0.025(0.077)$ & $-0.188(0.272)$ & $-0.001(0.095)$ & $-0.002(0.115)$ & $-0.190(0.154)$ \\
ASSETS & $-0.076^{* * *}(0.026)$ & $-0.002(0.076)$ & $-0.133^{* * *}(0.035)$ & $-0.101 * *(0.041)$ & $-0.173 * * *(0.057)$ \\
Dodd-Frank & $3.500^{* * *}(0.187)$ & & $2.242^{* * *}(0.209)$ & & $1.167 * * *(0.337)$ \\
cons & $-0.267(0.592)$ & $-3.029(1.852)$ & $2.026 * *(0.821)$ & $0.435(1.005)$ & $3.875 * *(1.539)$ \\
Observations & 1359 & 604 & 755 & 843 & 516 \\
Log likelihood & -630.11 & -110.26 & -333.83 & -323.21 & -162.55 \\
Pseudo R2 & 0.328 & 0.124 & 0.21 & 0.029 & 0.124 \\
\hline
\end{tabular}

Note: Logit estimates of likelihood of Dodd-Frank Act by US banks are defined in Table 9. Dodd-Frank is a binary variable that equal one after 2010, zero otherwise. This table reports the impacts of the explanatory of bank financial variables and standard errors are reported in parentheses. ${ }^{* *}, * *$, and * indicate statistical significance at the $1 \%, 5 \%$, and $10 \%$ levels, respectively.

Appendix A: Definition of variables

\begin{tabular}{ll}
\hline Variable & Description \\
\hline Return on Assets (ROA) & Earnings after tax divided by total assets and multiplied by 100 \\
Return on Equity (ROE) & Earnings after tax divided by firm's shareholders' equity and multiplied by 100 \\
Efficiency (ER) & The ratio of operating expenses to total operating income at given year. \\
Net Operating Income (NOITA) & The ratio of net operating income to total asset at given year. \\
Capital Assets Ratio (CAR) & The ratio of risk-weighted capital to total assets at given year. \\
Net Interest Margin (NIM) & The ratio of difference between received interest and paid interest to average invested \\
Loan to Assets Ratio (LR) & The ratio of total loans to total assets at given year. \\
Firm Size (ASSETS ) & Natural logarithm of firms assets \\
\hline
\end{tabular}

Source: Composed by authors 